\title{
Formation Characteristics of PCDD/Fs in the Co-combustion and Pyrolysis Process of Coal and Sewage Sludge
}

\author{
Mumin $\mathrm{Rao}^{1}$, Xiangbo Zou ${ }^{1}$, Ji Ye ${ }^{1}$, Yunfeng $\mathrm{Ma}^{2 *}$, Tieying Mao ${ }^{2}$, \\ Xiaoqing Lin $^{2 *}$, Xiaodong $\mathrm{Li}^{2}$, Jianhua Yan ${ }^{2}$, Shiwei Qin ${ }^{1}$, Cao Kuang ${ }^{1}$ \\ ${ }^{1}$ Guangdong Energy Group Science and Technology Research Institute Co., Ltd., Guangzhou \\ 510630, China \\ 2 State Key Laboratory for Clean Energy Utilization, Institute for Thermal Power Engineering, \\ Zhejiang University, Hangzhou 310027, China
}

\section{ABSTRACT}

Co-combustion technology of coal and sewage sludge (SS) was encouraged and recommended in China. Previous studies most focused on its influence on combustion characteristics, migration characteristics of heavy metals in fly ash, and emission of conventional pollutants, etc., but less reported the formation characteristics of polychlorinated- $\rho$-dibenzodioxins and dibenzofurans (PCDD/Fs). To well reveal it, this study carried out five parallel experiments, including the pyrolysis of SS, the combustion of SS, the co-combustion of coal and SS with the proportion of $0 \%, 2.5 \%$ and $5 \%$, respectively. The emission concentration of PCDD/Fs respectively increased from $0.42 \mathrm{ng} \mathrm{g}^{-1}$ $\left(0.0022 \mathrm{ng} \mathrm{I}\right.$-TEQ $\left.^{-1}\right)$ to $0.54 \mathrm{ng} \mathrm{g}^{-1}\left(0.0030 \mathrm{ng} \mathrm{I-TEQ} \mathrm{g}^{-1}\right)$ and $1.70 \mathrm{ng} \mathrm{g}^{-1}\left(0.0305 \mathrm{ng} \mathrm{I-TEQ}^{-1}\right)$ with increasing blending proportion of SS. The dominant part was also changed from PCDF $\left(0.32 \mathrm{ng} \mathrm{g}^{-1}\right.$ in $\mathrm{M}-0 \%, 0.38 \mathrm{ng} \mathrm{g}^{-1}$ in $\left.\mathrm{M}-2.5 \%\right)$ to PCDD (1.11 $\mathrm{ng} \mathrm{g}^{-1}$ in $\left.\mathrm{M}-5 \%\right)$. The formation concentration of $\mathrm{PCDD} /$ Fs in the combustion process of SS was about $0.34 \mathrm{ng} \mathrm{g}^{-1}\left(0.0019 \mathrm{ng} \mathrm{I-TEQ}^{-1}\right)$. In the pyrolysis

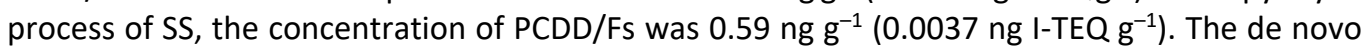
synthesis should be the major formation pathway of PCDD/Fs in the co-combustion process of coal and SS. On the basis of sufficient carbon sources, the PCA analysis revealed the chlorine source (Cl) and metal catalyst (Fe) should contribute a lot on the formation of PCDD/Fs. The results paved the way for further optimization on the operation of co-combustion of coal and SS and assist in controlling the PCDD/F emission from co-combustion process.

Received: July 23, 2021

Revised: August 29, 2021

Accepted: August 29, 2021

\author{
${ }^{*}$ Corresponding Authors: \\ Xiaoqing Lin \\ linxiaoqing@zju.edu.cn \\ Yunfeng Ma \\ happyjoe@zju.edu.cn
}

\section{Publisher:}

Taiwan Association for Aerosol Research

ISSN: $1680-8584$ print

ISSN: 2071-1409 online

Copyright: The Author(s). This is an open access article distributed under the terms of the Creative Commons Attribution License (CC BY 4.0), which permits unrestricted use, distribution, and reproduction in any medium, provided the original author and source are cited.

Keywords: Co-combustion of coal and sewage sludge, Polychlorinated- $\rho$-dibenzodioxins and dibenzofurans, Pyrolysis of sewage sludge, Formation pathways, Congener distribution

\section{INTRODUCTION}

With the development of social economy and the improvement of sewage treatment rate, the by-product treatment of sewage sludge (SS) also increased rapidly. Some source reported that the generation amount of municipal sewage sludge and industrial sewage sludge had reached $31 \mathrm{Mt}$ and $8.81 \mathrm{Mt}$, respectively, in 2018 (Intelligence Research Group, 2019). In addition, the SS treatment methods in China mainly included landfill, composting, natural drying and incineration, which account for 65\%, 15\%, 6\%, and 3\%, respectively (Intelligence Research Group, 2019). The huge amount of sludge had become an urgent problem for urban development, and better alternative disposal technology should be actively developed, for instance, co-combustion with coal. The coal fired power plant coupled with biomass power generation was an important development direction to achieve the low carbon transformation of coal-fired power generation and reduce more $\mathrm{CO}_{2}$ emissions.

Under this background, the co-combustion technology of SS in coal-fired power plant had been 
accepted and valued by local governments and plants in China. Relevant national departments had also issued a series of policies to promote the utilization of SS, and carried out the construction of demonstration projects. It was also required to accelerate the research and development, achievement transformation and standard formulation of key technologies of coal-fired coupled biomass power generation. For instance, the highest blending proportion of SS was recommended as $5 \%$ in the Emission Standard of Air Pollutants for Coal \& Sludge Co-fired Power Plant in Shanghai, China (Shanghai Municipal Bureau of Ecology and Environment, 2021).

Many researches had carried out co-combustion tests of SS and numerical simulation in coalfired power plant. Most of them mainly focused on the influence on the combustion characteristics of the boiler with different type of SS (Kijo-Kleczkowska et al., 2013; Xia et al., 2021; Zhu et al., 2015), different blending proportions (Kijo-Kleczkowska et al., 2016; Tan et al., 2017; Zhang et al., 2015), and different moisture content of SS (Tan et al., 2017; Zhang et al., 2015), etc., migration characteristics of heavy metals in fly ash (Namkung et al., 2018), and emission of conventional pollutants (Yang et al., 2016). All of which were quite important and basic information for further application of co-combustion technology. The co-combustion of SS also benefited to volume reduction, toxic organics destruction as well as energy recovery (Magdziarz and Werle, 2014; Werle and Wilk, 2010). However, less attention was focused on the emission of organic pollutants in the co-combustion process, especially the formation of polychlorinated dibenzo-p-dioxins and dibenzofurans (PCDD/Fs), which was heavily regulated in some industries, such as waste incineration.

$\mathrm{PCDD} /$ Fs was mainly generated by the homogeneous reaction in high temperature range (500$800^{\circ} \mathrm{C}$ ) and the heterogeneous reaction in low temperature range $\left(200-400^{\circ} \mathrm{C}\right)$ (Mckay, 2002; Ooi and Lu, 2011; Stanmore, 2004). The homogeneous reaction mainly contained the rearrangement of chlorophenols (CP), chlorobenzenes (CBz), and polychlorinated biphenyls (PCBs) (Cunliffe and Williams, 2009; Nganai et al., 2014). The heterogeneous reaction also involved precursor compounds (e.g., CP and CBz) (Babushok and Tsang, 2003; Evans and Dellinger, 2005) as well as de novo synthesis from carbon matrix or polycyclic aromatic hydrocarbons (PAHs) (Mckay, 2002; Ooi and $\mathrm{Lu}, 2011)$. CP-route synthesis was considered as an important and representative precursor pathway, $\mathrm{PCDD} /$ Fs can be directly condensed or rearranged by three $\mathrm{CPs}(2,4,6-, 2,3,4,6$ - and pentachlorophenol) (Lomnicki and Dellinger, 2002; 2003). Some studies reported that the chlorination of DD/DF also contributed to the PCDD/F formation, which could follow the sequence of $2 \rightarrow 8 \rightarrow 3 \rightarrow 7 \rightarrow 1$ $\rightarrow 4 \rightarrow 6 \rightarrow 9$ according to the electrophilic aromatic substitution mechanism (Luijk et al., 1992). The position of $2,3,7$, and 8 in PCDD/Fs were considered as the preferable chlorination position, which could be indicators for chlorination pathway (Ryu et al., 2003). The formation of PCDD/Fs were also closely related to some other factors, such as temperature, sources of chlorine and carbon, and metal catalysts (Mckay, 2002; Zhang et al., 2016).

To reveal the formation characteristics and pathways of PCDD/Fs in the co-combustion process of coal and SS, this study carried out a series of experiments with different blending proportions of SS. The results pave the way for further optimization on the operation of co-combustion of coal and SS and assist in controlling the PCDD/Fs emission from co-combustion process.

\section{METHODS}

\subsection{Materials and Pretreatment}

This study collected one typical coal and one sewage sludge (SS) from a coal-fired plant in Guangdong Province, China. The SS, used for coal co-combustion, was from a domestic wastewater treatment plant located in Guangdong Province, China. The proximate and ultimate analysis information was summarized in Table S1. The moisture content of SS was 54.2\%. Before experiments and analysis, the coal was dried in an oven at $105^{\circ} \mathrm{C}$ for over $24 \mathrm{~h}$, while the SS was directly used without drying process.

\subsection{Experimental Procedures}

Series experiments of coal and SS were carried out in a horizontal tube furnace (Fig. 1), and the experiment scheme was listed in Table 1 . This study mainly carried out five parallel experiments, including the pyrolysis of SS (S-P), the combustion of SS (S-C), the co-combustion of coal and SS with the proportion of $0 \%, 2.5 \%$ and $5 \%(\mathrm{M}-0 \%, \mathrm{M}-2.5 \%$, and $\mathrm{M}-5 \%$, respectively). The highest 


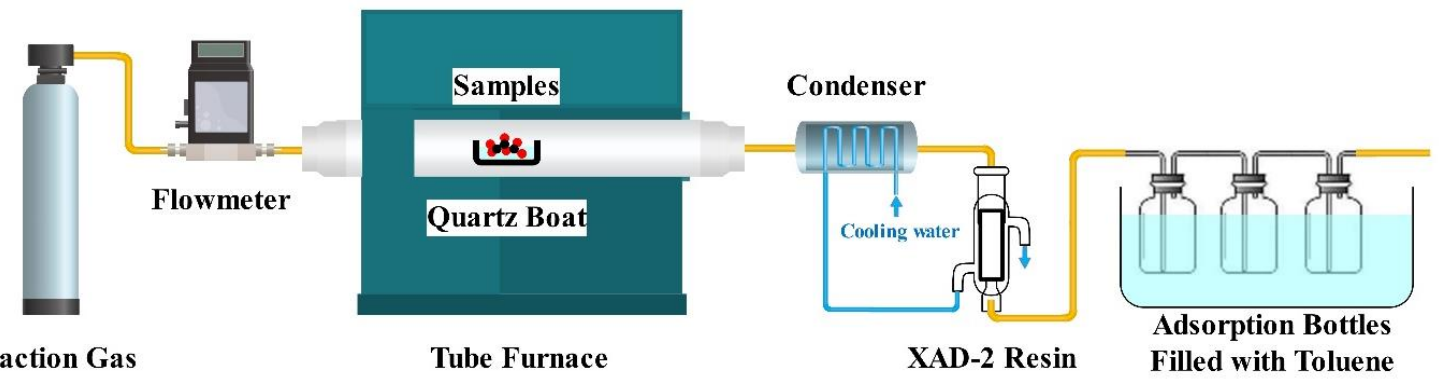

Reaction Gas

Tube Furnace

XAD-2 Resin

Filled with Toluene

Fig. 1. Schematic diagram of the experiment devices.

Table 1. Experiments scheme.

\begin{tabular}{llllllll}
\hline Types & Codes & Samples & $\begin{array}{l}\text { SS } \\
(\mathrm{g})\end{array}$ & $\begin{array}{l}\text { Coal } \\
(\mathrm{g})\end{array}$ & $\begin{array}{l}\text { Coal/SS weight } \\
\text { ratio }\end{array}$ & $\begin{array}{l}\text { Ambient gas } \\
\left(\mathrm{mL} \mathrm{min}^{-1}\right)\end{array}$ & $\begin{array}{l}\text { Temperature } \\
\left({ }^{\circ} \mathrm{C}\right)\end{array}$ \\
\hline Pyrolysis & $\mathrm{S}-\mathrm{P}$ & $\mathrm{SS}$ & 10 & 0 & $1.0 / 0$ & $\mathrm{~N}, 500$ & 850 \\
Combustion & $\mathrm{S}-\mathrm{C}$ & $\mathrm{SS}$ & 5 & 0 & $1.0 / 0$ & Air, 250 & 850 \\
Co-combustion & $\mathrm{M}-0 \%$ & Coal/SS & 0 & 2.5 & $0 / 1.0$ & Air, 250 & 850 \\
& $\mathrm{M}-2.5 \%$ & Coal/SS & 0.0625 & 2.4375 & $0.975 / 0.025$ & Air, 250 & 850 \\
& $\mathrm{M}-5 \%$ & Coal/SS & 0.125 & 2.375 & $0.95 / 0.05$ & Air, 250 & 850 \\
\hline
\end{tabular}

blending proportion of SS was recommended as 5\% in the Emission Standard of Air Pollutants for Coal \& Sludge Co-fired Power Plant in Shanghai, China (Shanghai Municipal Bureau of Ecology and Environment, 2021).

In order to clean the PCDD/Fs, other organics, chlorides and carbon possibly adsorbed onto the inner surface of the quartz tube, it was heated at $800^{\circ} \mathrm{C}$ for $15 \mathrm{~min}$ under the sweeping of $\mathrm{N}_{2}$ before each test. During each test, the first step was pre-heated the cleaned tube to $850^{\circ} \mathrm{C}$ under a heating rate of $20^{\circ} \mathrm{C} \mathrm{min}^{-1}$ with a continuous flow of reaction gas (Table 1); the second step was pushed a quartz boat loading prepared sample into the center of the quartz tube; the last step was placed each sample in the quartz tube at $850^{\circ} \mathrm{C}$ and reacted for $1 \mathrm{~h}$, and four parts were collected for further analysis of PCDD/Fs, including (1) XAD-II polymeric resin, (2) two bottles of toluene, (3) residues in quartz boat, and (4) sampling pipes.

\subsection{Analytical Methods}

All solid and liquid samples were stored in a cooler below $4{ }^{\circ} \mathrm{C}$ for further analysis. For the pretreatment and analysis of PCDD/Fs in thermally treated residues and off-gases of each sample, the pretreatment procedures followed the U.S. Environmental Protection Agency Method 1613 (U.S. PEA, 1994), which mainly contained spiking ${ }^{13} \mathrm{C}_{12}$-labelled PCDD/F standards, Soxhlet extraction, clean-up with multilayer silica gel column and basic-alumina column, quality assurance (QA), and quality control (QC). The purified samples were analyzed through a high-resolution gas chromatography/high-resolution mass spectrometry (HRGC/HRMS) (JMS-800D, JEOL, Japan) with a DB-5MS column (60 m length, $0.25 \mathrm{~mm}$ ID, $0.25 \mu \mathrm{m}$ film). The recoveries of PCDD/Fs standards range from $34.2 \%$ to $100.5 \%$, meeting the requirements of the method of U.S. EPA 1613 . The international toxic equivalents (I-TEQ) were calculated with NATO/CCMS factors (Bhavsar et al., 2008). More details were shown in previous studies (Chen et al., 2014; Lin et al., 2018).

The proximate and ultimate analysis were tested by differential thermal analyzer (DTA, 5E-IRSII, Kaiyuan Instruments Co., Ltd., China). The major elemental content of coal and SS was detected by X-ray fluorescence spectrometer (XRF, ARL ADVANT'X IntelliPower ${ }^{\mathrm{TM}}$ 4200, ThermoFisher Scientific, USA). The heavy metals (i.e., $\mathrm{Hg}, \mathrm{Pb}, \mathrm{Cd}, \mathrm{Cu}, \mathrm{Ni}, \mathrm{As}, \mathrm{Cr}$, and $\mathrm{Zn}$ ) in coal and SS was detected through an inductively coupled plasma combined with atomic emission spectrometry (ICP-AES, iCAP6300, ThermoFisher Scientific, USA) after the full digestion of coal and SS samples.

\subsection{Statistical Analysis}

In this study, total of 38 PCDD and 53 PCDF congeners was detected and analyzed, other than 
the theoretical number of 49 PCDD and 87 PCDF congeners, because the peak times of some $\mathrm{PCDD} / \mathrm{F}$ congeners were quite close and cannot be separated with each other.

To better evaluate the temperature effect on the distribution of PCDD/F congeners, the chlorination degree ( $d_{c}$, the average number of chlorine substituents) was introduced and was calculated by following equation:

$d_{c}=\frac{\sum C_{j} \times n_{j}}{C}$

where $j=4,5,6,7,8, C_{j}$ represents the concentration of each PCDD, PCDF, or PCDD/F, $n_{j}$ represents the number of substituted chlorines in each PCDD, PCDF, or PCDD/F; and $C$ represents the total concentration of PCDD, PCDF, or PCDD/F.

The relative importance of each congener was introduced and defined by their weight percentage within their own homologue group. The relative importance of OCDD and OCDF was calculated as their weight proportions in PCDD and PCDF, respectively. The detail calculation results were summarized in Table S2.

To better investigate the formation pathways of PCDD/F in each experiment, the content of each element in $\mathrm{M}-2.5 \%$ and $\mathrm{M}-5 \%$ was calculated based on them of SS and coal and their proportion, based on the following equation,

$C_{m}=C_{S S} \times P_{S S}+C_{\text {coal }} \times P_{\text {coal }}$

where $C_{m}$ represents the element content of mixed samples; $C_{s s}$ and $C_{\text {coal }}$ represent the element content in SS and coal, respectively; $P_{S S}$ and $P_{\text {coal }}$ represent the proportion of SS and coal.

\section{RESULTS AND DISCUSSION}

\subsection{The Element Content}

In this study, the contents of basic elements and trace heavy metal elements were shown in Table 2. The sewage sludge contained abundant carbon source (C, 6.04\%), chlorine source $(\mathrm{Cl}$, $0.32 \%$ ), metal catalysts ( $\mathrm{Fe}, 2.54 \% ; \mathrm{Cu}, 85.49 \mathrm{mg} \mathrm{kg}^{-1} ; \mathrm{Ni}, 38.13 \mathrm{mg} \mathrm{kg}^{-1}$ ), and inhibiting element of PCDD/Fs (S, 1.24\%; Ca, 9.59\%). The carbon source, chlorine source, and metal catalysts would support a lot on the formation of PCDD/Fs, while the $S$ might inhibit the formation of PCDD/Fs. In addition, the content of all trace heavy metals was lower than the Control Standards of Pollutants in Sludge for Agriculture Use (GB 4284-2018). For coal, it contained much carbon (66.73\%) but less

Table 2. Contents of basic elements and trace heavy metals of SS, coal and their mixture.

\begin{tabular}{cllll}
\hline Elements & SS & M-0\% (Coal) & M-2.5\% & M-5\% \\
\hline Basic elements (\%) & & & & \\
$\mathrm{C}$ & 6.04 & 66.73 & 65.21 & 63.70 \\
$\mathrm{Cl}$ & 0.32 & 0.07 & 0.08 & 0.09 \\
$\mathrm{Fe}$ & 2.54 & 0.45 & 0.50 & 0.55 \\
$\mathrm{~S}$ & 1.24 & 0.16 & 0.19 & 0.21 \\
$\mathrm{Ca}$ & 9.59 & 0.77 & 0.99 & 1.21 \\
Trace heavy metal elements $\left(\mathrm{mg} \mathrm{kg}^{-1}\right)$ & & & \\
$\mathrm{Hg}$ & 1.02 & 1.11 & 1.11 & 1.11 \\
$\mathrm{~Pb}$ & 27.75 & 1.99 & 2.63 & 3.28 \\
$\mathrm{Cd}$ & 1.77 & 0.20 & 0.24 & 0.28 \\
$\mathrm{Cu}$ & 85.49 & 0.58 & 2.70 & 4.83 \\
$\mathrm{Ni}$ & 38.13 & 7.40 & 8.17 & 8.94 \\
$\mathrm{As}$ & 21.16 & 1.57 & 2.06 & 2.55 \\
$\mathrm{Cr}$ & 10.91 & 11.92 & 12.94 \\
$\mathrm{Zn}$ & 51.44 & 17.22 & 24.31 & 31.40 \\
\hline
\end{tabular}


chlorine (0.07\%), metal catalysts ( $\mathrm{Fe}, 0.45 \% ; \mathrm{Cu}, 0.58 \mathrm{mg} \mathrm{kg}^{-1} ; \mathrm{Ni}, 7.40 \mathrm{mg} \mathrm{kg}^{-1}$ ), and inhibiting element of PCDD/Fs (S, 0.16\%; Ca, 0.77\%).

After fully blending of SS and coal, the proportion of carbon was only slightly decreased with increasing proportion of SS by $2.5 \%$ and $5 \%$, while the proportion of other chlorine, metal catalysts and inhibiting elements was increased, especially the key catalytic metal of $\mathrm{Cu}$. All of which would influence a lot on the formation of PCDD/Fs.

\subsection{The PCDD/F Content}

\subsubsection{Pyrolysis and combustion and of sewage sludge}

The PCDD/F concentrations of each experiment were summarized in Table 3 . In the pyrolysis

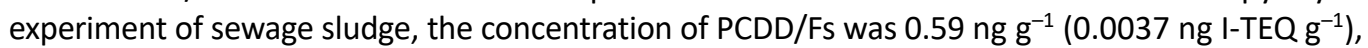
dominated by PCDDs $\left(0.38 \mathrm{ng} \mathrm{g}^{-1}\right)$. The chlorination degree of PCDDs $\left(d_{c-P C D D s}, 4.76\right)$ show significant difference with that of PCDFs $\left(d_{C-P C D F s}, 6.34\right)$, and the chlorination degree of PCDD/Fs $\left(d_{C-P C D D / F s}\right)$ was 5.30. It revealed that the existing organic pollutants (Chanaka Udayanga et al., 2019), carbon source, chlorine source, and metal catalysts in SS were enough to generate PCDD/Fs, and the anaerobic atmosphere might reduce the decomposition of PCDD/Fs. In the combustion experiment of SS, the generation of PCDD/Fs was about $0.34 \mathrm{ng} \mathrm{g}^{-1}\left(0.0019 \mathrm{ng}\right.$ I-TEQ $\left.\mathrm{g}^{-1}\right)$, which was evenly distributed by PCDDs $\left(0.17 \mathrm{ng} \mathrm{g}^{-1}\right)$ and PCDFs $\left(0.17 \mathrm{ng} \mathrm{g}^{-1}\right)$. All these values were lower, compared with pyrolysis experiment. The $d_{c-P C D D s}, d_{c-P C D F s}$, and $d_{c-P C D D / F s}$ were respectively increased to $5.57,6.4$, and 6.04 compared with the pyrolysis experiment, which was attributed to the introduce of oxygen.

Oxygen was an essential factor for PCDD/F formation by de novo synthesis (Pekárek et al., 2001; Stieglitz, 1998). In the formation process of PCDD/Fs, oxygen can facilitate to convert inorganic chlorine into organic chlorine and the chlorination of carbon (López et al., 2008; Weber et al., 2001). In addition, it can also promote the oxidation of carbon structure and release PCDD/Fs (Wikström et al., 2003). Since the sludge itself contained oxygen (Table S1), it should meet the needs of PCDD/F formation. However, in the combustion condition, more oxygen might promote the decomposition of dioxins at high temperature $\left(850^{\circ} \mathrm{C}\right)$ (Mckay, 2002).

\subsubsection{Co-combustion of coal and sewage sludge}

Three co-combustion experiments were carried out in this study with three blending proportion of SS, i.e., $0 \%, 2.5 \%$, and $5 \%$, respectively. For experiment $\mathrm{M}-0 \%$, the concentration of

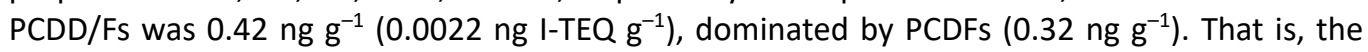
generation of PCDD/Fs was higher than the emission during the combustion process of SS. The $d_{C-P C D D s}, d_{C-P C D F s}$, and $d_{C-P C D D / F s}$ were further increased to $6.36,6.49$, and 6.46 compared with the combustion experiment of SS, respectively. The different chemical characteristics of SS and coal should be the major influencing factor, i.e., comparing with the abundant carbon source, chlorine source, metal catalysts, and inhibiting elements of SS, coal had much higher content of carbon source and enough support of other conditions.

For experiment $\mathrm{M}-2.5 \%$, the PCDD/F concentration was increased to $0.54 \mathrm{ng} \mathrm{g}^{-1}(0.0030$ ng I-TEQ $\left.\mathrm{g}^{-1}\right)$, dominated by PCDF $\left(0.38 \mathrm{ng} \mathrm{g}^{-1}\right)$. The emission of PCDDs and PCDFs were both increased by $0.06 \mathrm{ng} \mathrm{g}^{-1}$. The $d_{C-P C D D s}, d_{C-P C D F s}$, and $d_{C-P C D D / F s}$ were further increased to $6.31,7.12$,

Table 3. PCDD/F concentrations of different experiments ( $\mathrm{g} \mathrm{g} \mathrm{g}^{-1}$ for PCDDs, PCDFs and PCDD/Fs; $n g$ I-TEQ $\mathrm{g}^{-1}$ for toxic PCDD/Fs).

\begin{tabular}{llllll}
\hline & $S-P$ & $S-C$ & $M-0 \%$ & $M-2.5 \%$ & $M-5 \%$ \\
\hline PCDDs & $\mathbf{0 . 3 8} \pm \mathbf{0 . 0 2}$ & $\mathbf{0 . 1 7} \pm \mathbf{0 . 0 1}$ & $\mathbf{0 . 1 0} \pm \mathbf{0 . 0 1}$ & $\mathbf{0 . 1 6} \pm \mathbf{0 . 0 2}$ & $\mathbf{1 . 1 1} \pm \mathbf{0 . 0 8}$ \\
PCDFs & $\mathbf{0 . 2 0} \pm \mathbf{0 . 0 1}$ & $\mathbf{0 . 1 7} \pm \mathbf{0 . 0 1}$ & $\mathbf{0 . 3 2} \pm \mathbf{0 . 0 2}$ & $\mathbf{0 . 3 8} \pm \mathbf{0 . 0 1}$ & $\mathbf{0 . 5 9} \pm \mathbf{0 . 0 9}$ \\
PCDD/Fs & $\mathbf{0 . 5 9} \pm \mathbf{0 . 0 2}$ & $\mathbf{0 . 3 4} \pm \mathbf{0 . 0 1}$ & $\mathbf{0 . 4 2} \pm \mathbf{0 . 0 1}$ & $\mathbf{0 . 5 4} \pm \mathbf{0 . 0 2}$ & $\mathbf{1 . 7 0 \pm \mathbf { 0 . 0 9 }}$ \\
Toxic PCDD/Fs & $\mathbf{0 . 0 0 3 7} \pm \mathbf{0 . 0 0 0 4}$ & $\mathbf{0 . 0 0 1 9} \pm \mathbf{0 . 0 0 0 2}$ & $\mathbf{0 . 0 0 2 2} \pm \mathbf{0 . 0 0 0 2}$ & $\mathbf{0 . 0 0 3 0} \pm \mathbf{0 . 0 0 0 2}$ & $\mathbf{0 . 0 3 0 5} \pm \mathbf{0 . 0 0 0 6}$ \\
PCDFs/PCDDs & 0.52 & 1.02 & 3.26 & 238 & 0.54 \\
PCDFs/(PCDD/Fs) & 0.34 & 0.50 & 0.77 & 0.70 & 0.35 \\
$d_{c-P C D D s}$ & 4.76 & 5.57 & 6.36 & 6.31 & 4.70 \\
$d_{C-P C D F s}$ & 6.34 & 6.49 & 6.49 & 7.12 & 7.28 \\
$d_{C-P C D D / F s}$ & 5.30 & 6.04 & 6.46 & 6.88 & 5.60 \\
\hline
\end{tabular}


and 6.88 compared with the combustion experiment of SS, respectively. For experiment M-5\%, the concentration of PCDD/Fs was further increased to $1.70 \mathrm{ng} \mathrm{g}^{-1}\left(0.0305 \mathrm{ng} \mathrm{I-TEQ} \mathrm{g}{ }^{-1}\right)$, dominated by PCDDs $\left(1.11 \mathrm{ng} \mathrm{g}^{-1}\right)$. The $d_{C-P C D D s}, d_{C-P C D F s}$, and $d_{C-P C D D / F s}$ were further increased to $4.70,7.28$, and 5.60 compared with the combustion experiment of SS, respectively. Herein, the emission of PCDD/Fs was increased with the increasing proportion of SS, especially from $2.5 \%$ to $5 \%$, which was mainly caused by more discharge of PCDDs $\left(0.95 \mathrm{ng} \mathrm{g}^{-1}\right)$. In addition, the $d_{c-P C D D s}$ was decreased as the blending proportion of SS increased, while the $d_{c-P C D F s}$ was increased. All of which can attributed to the well support of oxygen and the increasing amount of chlorine source, metal catalysts (Fe and $\mathrm{Cu}$ ) (Table 2).

\subsection{Influence on PCDD/Fs Congeners/Homologues Distribution}

\subsubsection{Pyrolysis and combustion of sewage sludge}

Figs. 2(a) and 2(b) showed the distribution of PCDD/Fs homologues on concentration and proportion, respectively. In pyrolysis experiment of SS, low-chlorinated homologues, TCDDs (0.2359 $\left.\mathrm{ng} \mathrm{g}^{-1}, 40 \%\right)$ and PeCDDs $\left(0.0864 \mathrm{ng} \mathrm{g}^{-1}, 15 \%\right)$, were the major parts of PCDDs, while PCDFs showed less difference between low-chlorinated homologues and high-chlorinated homologues and was dominated by PeCDFs (0.0543 $\left.\mathrm{ng} \mathrm{g}^{-1}, 9 \%\right)$ and OCDF (0.0832 $\left.\mathrm{ng} \mathrm{g}^{-1}, 14 \%\right)$. Compared with the pyrolysis process of SS, low-chlorinated homologues, TCDDs (0.0389 $\mathrm{ng} \mathrm{g}^{-1}$,
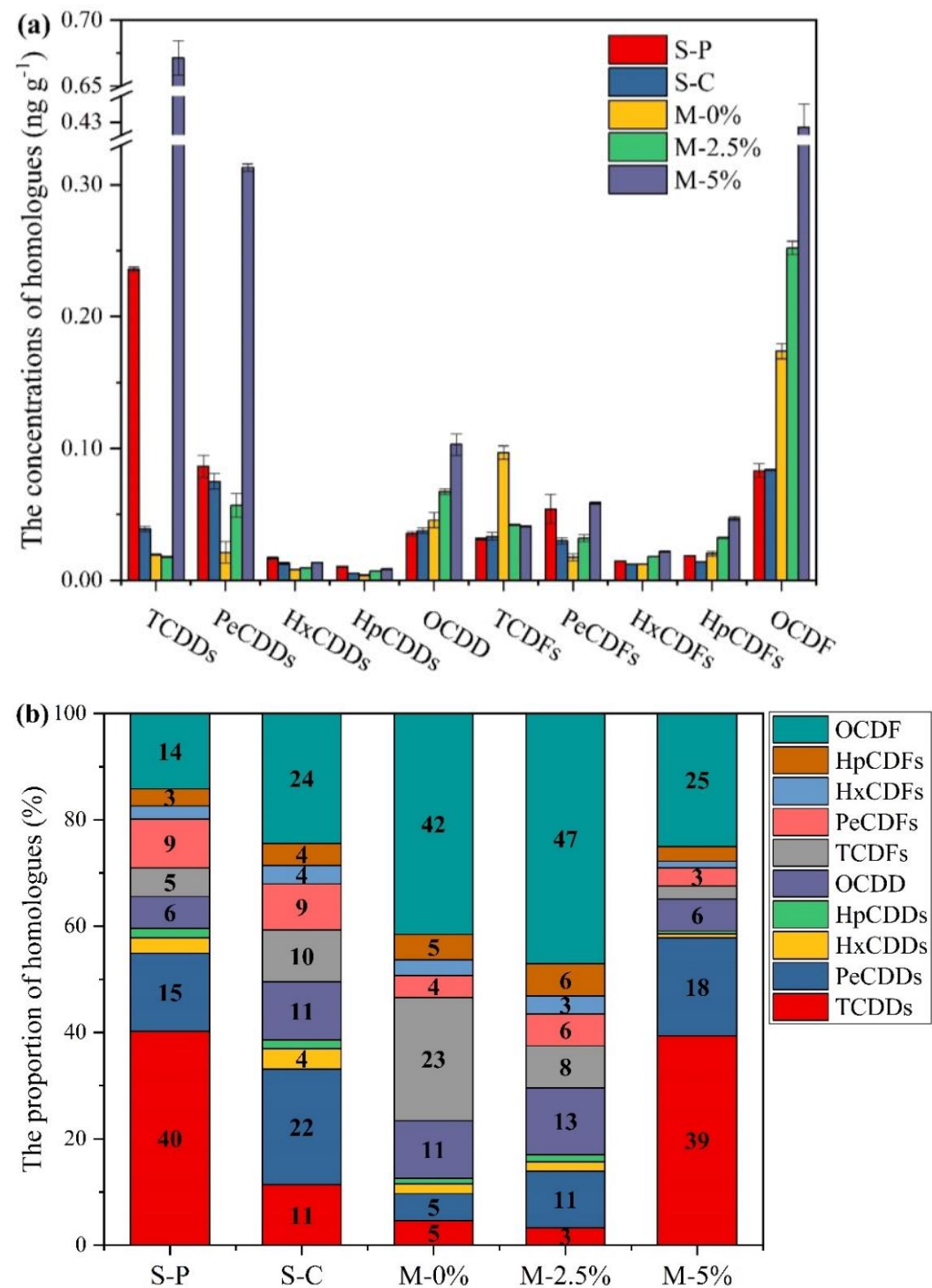

Fig. 2. The concentration and proportion of PCDD/F homologues. 
$11 \%)$ and PeCDDs (0.0749 $\left.\mathrm{ng} \mathrm{g}^{-1}, 22 \%\right)$, were still the domination of PCDDs in the combustion process of SS, but the proportion of OCDD was increased from $6 \%$ to $11 \%$. Except OCDD, the concentrations of other four PCDD homologues were decreased with varying degrees. The total proportion of PCDFs had increased from $34 \%$ to $51 \%$, mainly divided by TCDFs $\left(0.0333 \mathrm{ng} \mathrm{g}^{-1}\right.$, $10 \%)$, PeCDFs (0.0299 $\left.\mathrm{ng} \mathrm{g}^{-1}, 9 \%\right)$, and OCDF $\left(0.0837 \mathrm{ng} \mathrm{g}^{-1}, 24 \%\right)$. All these changes resulted in the increasing of $d_{C-P C D D s}, d_{C-P C D F s}$, and $d_{C-P C D D / F s}$.

\subsubsection{Co-combustion of coal and sewage sludge}

In co-combustion experiment of M-0\%, PCDFs was the absolutely dominant part (77\%) as mentioned above, resulting from the high concentration and proportion of TCDFs $\left(0.0968 \mathrm{ng} \mathrm{g}^{-1}\right.$, $23 \%)$ and OCDF (0.1737 $\left.\mathrm{ng} \mathrm{g}^{-1}, 42 \%\right)$. The PCDDs mainly consisted of TCDDs $\left(0.0194 \mathrm{ng} \mathrm{g}^{-1}, 5 \%\right)$, PeCDDs $\left(0.0212 \mathrm{ng} \mathrm{g}^{-1}, 5 \%\right)$, and OCDD $\left(0.0456 \mathrm{ng} \mathrm{g}^{-1}, 11 \%\right)$. Compared with the combustion of SS, the lower concentration of PCDDs in experiment $\mathrm{M}-0 \%$ was caused by the decreasing concentration of TCDDs, PeCDDs, HxCDDs, and HpCDDs, while the higher concentration of OCDF was resulted from the significant increase of TCDFs and OCDF. After increasing the blending proportion of SS from $0 \%$ to $2.5 \%$, the concentrations of PeCDD/Fs, HxCDD/Fs, HpCDD/Fs, and OCDD/F, especially the PeCDDs (from $0.0212 \mathrm{ng} \mathrm{g}^{-1}$ to $0.0568 \mathrm{ng} \mathrm{g}^{-1}$ ), OCDD (from $0.0456 \mathrm{ng} \mathrm{g}^{-1}$ to $0.0674 \mathrm{ng} \mathrm{g}^{-1}$ ), and OCDF (from $0.1737 \mathrm{ng} \mathrm{g}^{-1}$ to $0.2520 \mathrm{ng} \mathrm{g}^{-1}$ ), were all increased with varying degrees, which resulted in the increased concentration of total PCDD/Fs. Only the concentrations of TCDDs and TCDFs showed decreasing trend, especially TCDFs (from $0.0968 \mathrm{ng} \mathrm{g}^{-1}$ to $0.0422 \mathrm{ng} \mathrm{g}^{-1}$ ). Meanwhile, the proportions of PeCDD/Fs, HxCDD/Fs, HpCDD/Fs, and OCDD/F were increased with varying degree, and the proportions of TCDD/Fs decreased. After further increased the blending proportion of SS from $2.5 \%$ to $5 \%$, almost the concentrations of all PCDD/F homologues increased other than TCDFs, resulting the huge increase of total concentration of PCDD/Fs. Among the them, TCDDs contributed most (from $0.0177 \mathrm{ng} \mathrm{g}^{-1}$ to $0.6713 \mathrm{ng} \mathrm{g}^{-1}$ ); PeCDDs contribute much (from $0.0568 \mathrm{ng} \mathrm{g}^{-1}$ to $0.3131 \mathrm{ng} \mathrm{g}^{-1}$ ); and OCDF also contributed a lot (from $0.2520 \mathrm{ng} \mathrm{g}^{-1}$ to $0.4261 \mathrm{ng} \mathrm{g}^{-1}$ ). At the same time, the proportions of TCDDs and PeCDDs also increased a lot to $39 \%$ and $18 \%$, respectively. However, due to the huge increase of TCDDs and PeCDDs, the proportions of other homologues decreased with varying degrees.

\subsection{The Formation Pathway of PCDD/Fs}

As mentioned above, the homogeneous reaction mainly involved the rearrangement of chlorinated precursors, such as CP, CBz, and PCBs (Cunliffe and Williams, 2009; Nganai et al., 2014). The heterogeneous reaction involved not only precursor compounds ( $\mathrm{CP}$ and $\mathrm{CBz}$ ) (Babushok and Tsang, 2003; Evans and Dellinger, 2005), but also the de novo synthesis (from carbon matrix or from PAHs) (Mckay, 2002; Ooi and Lu, 2011). In addition, the experiment temperature was stably hold on $850^{\circ} \mathrm{C}$, which could better support the homogeneous reaction. Herein, this study tried to reveal the potential formation pathway and key influence factors of PCDD/Fs in the co-combustion process of SS and coal.

\subsubsection{Precursors synthesis}

As for the CP-route, the representatives of PCDD and PCDF congeners were 1,3,6,8- and 1,3,7,9TCDDs, and 2,4,6,8- and 1,2,3,8/1,2,3,6/1,4,6,9/1,6,7,8/1,2,3,4/2,3,6,8-TCDFs, respectively. As mentioned above, these congeners can be directly condensed or rearranged by three CPs $(2,4,6$-, 2,3,4,6- and 2,3,4,5,6-chlorophenol) (Weber and Hagenmaier, 1999). Previous studies also identified 2,4,6,8- and 1,2,3,8/1,2,3,6/1,4,6,9/1,6,7,8/1,2,3,4/2,3,6,8-TCDFs, 1,2,4,6,8/1,2,4,7,9-, $1,2,3,6,8$ - and 1,2,3,7,9-PeCDDs, and 1,2,3,4,6,8/1,2,3,4,7,9-HxCDD as representative congeners based on their high correlation with 1,3,6,8- and 1,3,7,9-TCDDs (Zhang et al., 2017b; Chen et al., 2018). To obtain reliable mechanism by means of data analysis, the relative importance of these representatives was introduced in this study, which was calculated through their proportions (\%) within their own homologue group (Table 4). The results showed an average contribution of 22.38\%-27.96\% was from the CP-route representatives in PCDD side, while it only contribute about 6.86\%-7.99\% in PCDF side. In addition, the contribution to PCDDs and PCDFs were both decreased as the blending proportion of SS increased.

Based on the homologue profiles, the PCDD/F congeners were also analyzed by principal 
Table 4. The relative importance of CP-route congeners (\%).

\begin{tabular}{|c|c|c|c|c|c|}
\hline Congeners & S-P & $\mathrm{S}-\mathrm{C}$ & $\mathrm{M}-0 \%$ & $M-2.5 \%$ & $M-5 \%$ \\
\hline 1,3,6,8-TCDD & 3.42 & 19.29 & 41.11 & 33.92 & 2.20 \\
\hline $1,3,7,9-T C D D$ & 2.37 & 10.36 & 22.00 & 20.84 & 3.39 \\
\hline Sum of TCDD & 5.79 & 29.65 & 63.11 & 54.76 & 5.59 \\
\hline 1,2,4,7,9/1,2,4,6,8-PeCDD & 91.55 & 87.80 & 69.10 & 87.59 & 88.66 \\
\hline $1,2,3,6,8-\mathrm{PeCDD}$ & 0.62 & 5.03 & 10.29 & 3.85 & 0.67 \\
\hline 1,2,3,7,9-PeCDD & 2.58 & 3.54 & 7.21 & 2.87 & 2.24 \\
\hline Sum of PeCDD & 94.75 & 96.38 & 86.60 & 94.31 & 91.56 \\
\hline $1,2,3,4,6,8-\mathrm{HxCDD}$ & 37.74 & 62.59 & 18.02 & 14.85 & 37.13 \\
\hline Average of PCDD & 23.05 & 31.44 & 27.96 & 27.32 & 22.38 \\
\hline $2,4,6,8-\mathrm{TCDF}$ & 8.73 & 4.34 & 10.09 & 2.87 & 2.68 \\
\hline $1,2,3,8 / 1,2,3,6 / 1,4,6,9 / 1,6,7,8 / 1,2,3,4 / 2,3,6,8-T C D F$ & 18.77 & 21.64 & 5.89 & 12.31 & 11.05 \\
\hline Sum of TCDF & 27.49 & 25.98 & 15.99 & 15.18 & 13.72 \\
\hline Average of PCDF & 13.75 & 12.99 & 7.99 & 7.59 & 6.86 \\
\hline Average of PCDD/F & 20.72 & 26.82 & 22.97 & 22.39 & 18.50 \\
\hline
\end{tabular}

component analysis (PCA) (Fig. S1). The data characteristics of TCDD, PeCDD, HxCDD and TCDF congeners were well explained by Factor 1 and Factor 2 with the total variance of $100 \%$. However, the distribution of six CP-route representatives were not consistent with our previous studies (Zhang et al., 2017b; Zhan et al., 2019; Wang et al., 2020) excepting of 1,3,6,8- and 1,3,7,9-TCDDs, and other congeners were not all distributed in the lower left quadrant and close to each other. All of which indicated that the CP-route would not be the major formation pathway of PCDDs and PCDFs, and higher proportion of SS reduced the potential contribution of CP-route.

As for the pyrolysis of SS, the contribution of CP-route representatives was lower than those in the co-combustion of coal and SS, indicating the CP-route could also not the major formation pathway of PCDD/Fs. In contrary, the contribution of these representatives in the combustion process of SS was higher than the co-combustion process of coal and SS, which could attribute to the more abundant organic pollutants in SS than coal (Chanaka Udayanga et al., 2019).

The signal intensity of 2,3,7,8-substituted congeners were summarized in Table 5 . Some studies reported that the chlorination of DD/DF could follow the sequence of $2 \rightarrow 8 \rightarrow 3 \rightarrow 7 \rightarrow 1 \rightarrow 4$ $\rightarrow 6 \rightarrow 9$ (Luijk et al., 1992). The average signal intensity of 2,3,7,8-substituted PCDDs significantly decreased from $16.22 \%$ to $15.15 \%$, and $11.03 \%$ with the increasing blending proportion of SS in co-combustion experiments ( $0 \%, 2.5 \%$, and $5 \%$, respectively), while those of 2,3,7,8-substituted PCDFs was slowly increased from $15.25 \%$ to $15.67 \%$, and $16.67 \%$, respectively. All of which indicated that the chlorination pathway of DD/F could not be the major formation pathway of PCDDs, but it partly contributed to the formation of PCDFs. As for the pyrolysis and combustion process of SS, the average signal intensity of 2,3,7,8-substituted PCDDs and PCDFs was generally lower than those in the co-combustion process of coal and SS, which could explain the less contribution of the chlorination pathway of DD/F.

As mentioned above, the PCDD/F concentration decreased after introducing oxygen into combustion process of SS, and the proportion of precursor pathway obviously increased. However, the chlorination pathway only increased slightly. However, these two formation pathways of $\mathrm{PCDD} /$ Fs reduced with increasing proportion of SS in co-combustion experiments, although the $\mathrm{PCDD} / \mathrm{F}$ formation obviously increased. In pyrolysis and combustion process of SS, the decreasing concentration of PCDD/Fs and decreasing proportion of precursor and chlorination pathway could also influenced by the high content of $S$ in SS, which can inhibit PCDD/F formation by following aspects: (1) decreasing chlorine source through convert $\mathrm{Cl}_{2}$ into $\mathrm{HCl}$ (Ma et al., 2021; Raghunathan and Gullett, 1996), (2) decreasing $\mathrm{Cu} / \mathrm{CuO}$ or other metals/metal oxides through convert them into sulfate (Ma et al., 2021; Shao et al., 2010). As for the decreasing contribution of precursor and chlorination pathways in co-combustion process, which could attribute to the increasing performance of de novo synthesis reaction. It reflected the introduced $\mathrm{S}$ could not inhibit the formation of PCDD/Fs. In addition, it also revealed that higher blending proportion of SS would result in higher PCDD/F formation and emission. 
Table 5. PCDD/F-Hagenmaier profile in each experiments (\%).

\begin{tabular}{|c|c|c|c|c|c|}
\hline Congeners & $S-P$ & $\mathrm{~S}-\mathrm{C}$ & $\mathrm{M}-0 \%$ & $M-2.5 \%$ & $M-5 \%$ \\
\hline $2,3,7,8-T C D D$ & 0.59 & 0.91 & 2.55 & 4.94 & 4.00 \\
\hline $1,2,3,7,8-\mathrm{PeCDD}$ & 2.10 & 0.56 & 1.06 & 1.02 & 0.92 \\
\hline $1,2,3,4,7,8-\mathrm{HxCDD}$ & 2.79 & 2.83 & 2.44 & 3.41 & 3.43 \\
\hline $1,2,3,6,7,8-\mathrm{HxCDD}$ & 8.19 & 5.02 & 4.42 & 4.75 & 4.66 \\
\hline $1,2,3,7,8,9-\mathrm{HxCDD}$ & 7.99 & 5.19 & 8.32 & 7.83 & 7.01 \\
\hline $1,2,3,4,6,7,8-H p C D D$ & 51.75 & 52.04 & 48.35 & 41.66 & 47.89 \\
\hline OCDD & 9.14 & 22.08 & 46.42 & 42.47 & 9.28 \\
\hline PCDD average & 11.80 & 12.66 & 16.22 & 15.15 & 11.03 \\
\hline $2,3,7,8-\mathrm{TCDF}$ & 1.80 & 1.69 & 3.38 & 2.49 & 3.23 \\
\hline $1,2,3,7,8-\mathrm{PeCDF}$ & 1.14 & 2.13 & 5.81 & 4.19 & 2.50 \\
\hline $2,3,4,7,8 / 1,2,4,8,9-\mathrm{PeCDF}$ & 0.83 & 3.07 & 4.87 & 3.49 & 1.09 \\
\hline $1,2,3,4,7,8-\mathrm{HxCDF}$ & 9.28 & 8.40 & 7.16 & 6.79 & 6.84 \\
\hline $1,2,3,6,7,8-\mathrm{HxCDF}$ & 10.03 & 8.84 & 8.52 & 8.01 & 9.66 \\
\hline $2,3,4,6,7,8 / 1,2,3,6,8,9-\mathrm{HxCDF}$ & 4.06 & 4.04 & 3.16 & 2.46 & 3.07 \\
\hline $1,2,3,7,8,9 / 1,2,3,4,8,9-\mathrm{HxCDF}$ & 11.16 & 10.82 & 7.78 & 8.06 & 7.61 \\
\hline $1,2,3,4,6,7,8-\mathrm{HpCDF}$ & 60.96 & 60.10 & 47.16 & 43.02 & 50.26 \\
\hline $1,2,3,4,7,8,9-\mathrm{HpCDF}$ & 11.01 & 10.07 & 10.50 & 11.26 & 10.77 \\
\hline OCDF & 41.17 & 48.35 & 54.23 & 66.91 & 71.71 \\
\hline PCDF average & 15.14 & 15.75 & 15.25 & 15.67 & 16.67 \\
\hline PCDD/F average & 13.77 & 14.48 & 15.65 & 15.46 & 14.35 \\
\hline
\end{tabular}

\subsubsection{Correlation analysis}

To better reveal the formation pathways and influence factors of PCDD/Fs in the co-combustion process, this study also analyzed the relationship among the PCDD/F homologues, chlorination degree, and key elements in coal and SS based on the data in Table 2, Table 3, and Fig. 2(a), and the analysis results were shown in Fig. 3. These factors distributed in the lower left quadrant (TCDF, C, Hg, $d_{C-P C D D s}$, and $d_{C-P C D F s}$ ) and higher right quadrant (other factors), which mean the correlation between factors in lower left quadrant and other factors in higher right quadrant was not strong. The reason could be attributed to the influence of inhibition element (S) in higher right quadrant. In the higher right quadrant, chlorine source $(\mathrm{Cl})$, metal catalyst (Fe), and most PCDD/F homologues excepting TCDFs distributed closely and showed important relationship between each other, which was closely related to the formation mechanism of PCDD/Fs. In addition, the points of $\mathrm{Cu}$ and some other factors were not found in Fig. 3, which indicated their less relationship or even contribution to the formation of PCDD/Fs in the co-combustion process. Overall, the de novo synthesis should be the major formation pathway of PCDD/Fs in the co-combustion process of coal and SS.

\section{CONCLUSIONS}

This study carried out five parallel experiments, including the pyrolysis of SS, the combustion of SS, the co-combustion of coal and SS with the proportion of $0 \%, 2.5 \%$ and $5 \%$, respectively.

As the blending proportion increased, the emission concentration of PCDD/Fs respectively increased from $0.42 \mathrm{ng} \mathrm{g}^{-1}\left(0.0022 \mathrm{ng} \mathrm{I-TEQ} \mathrm{g}^{-1}\right)$ to $0.54 \mathrm{ng} \mathrm{g}^{-1}\left(0.0030 \mathrm{ng} \mathrm{I-TEQ} \mathrm{g}^{-1}\right)$ and $1.70 \mathrm{ng} \mathrm{g}^{-1}$

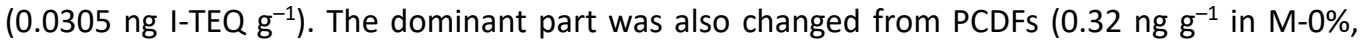
$0.38 \mathrm{ng} \mathrm{g}^{-1}$ in $\left.\mathrm{M}-2.5 \%\right)$ to PCDDs (1.11 $\mathrm{ng} \mathrm{g}^{-1}$ in $\left.\mathrm{M}-5 \%\right)$. In addition, the PCDFs was always dominated by OCDF (25\%-47\%) and TCDFs ( $8 \%-23 \%)$, while PCDDs was always dominated by TCDDs (3\%-39\%), PeCDDs (5\%-18\%), and OCDD (6\%-13\%).

The formation concentration of PCDD/Fs in the combustion process of SS was about $0.34 \mathrm{ng} \mathrm{g}^{-1}$ (0.0019 $\left.\mathrm{ng} \mathrm{I-TEQ} \mathrm{g}^{-1}\right)$, which was evenly distributed by PCDDs $\left(0.17 \mathrm{ng} \mathrm{g}^{-1}\right)$ and PCDFs $\left(0.17 \mathrm{ng} \mathrm{g}^{-1}\right)$. In the pyrolysis process of SS, the concentration of PCDD/Fs was $0.59 \mathrm{ng} \mathrm{g}^{-1}\left(0.0037 \mathrm{ng} \mathrm{l-TEQ} \mathrm{g}^{-1}\right)$, dominated by PCDDs $\left(0.38 \mathrm{ng} \mathrm{g}^{-1}\right)$. The TCDDs, PeCDDs, OCDD, TCDFs, PeCDFs, and OCDF were the dominant homologues. 


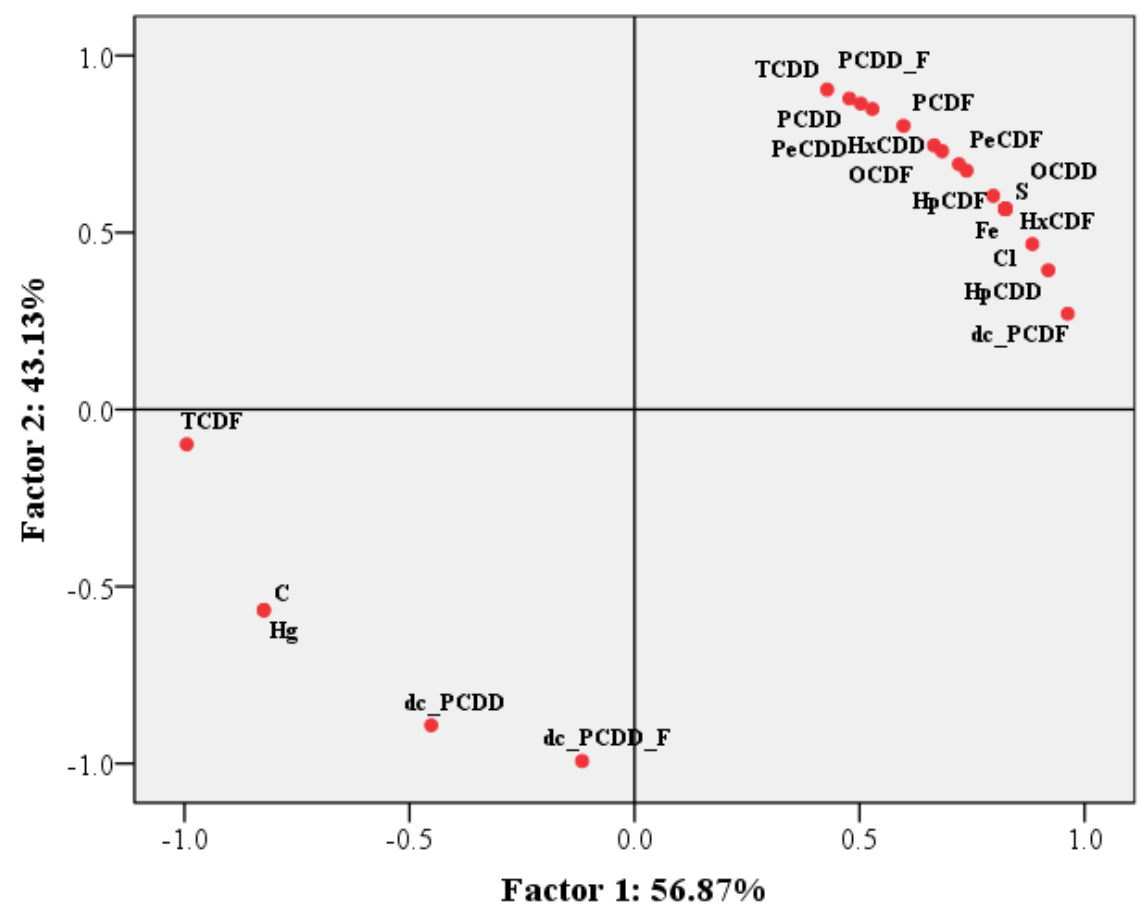

Fig. 3. Principal component analysis results of PCDD/F homologues, chlorination degree, and key elements.

The de novo synthesis should be the major formation pathway of PCDD/Fs in the co-combustion process of coal and SS. The relative importance analysis revealed that the CP-route and the chlorination of DD/F were not the major formation pathway of PCDD/Fs. On the basis of sufficient carbon sources, the PCA analysis revealed the chlorine source $(\mathrm{Cl})$ and metal catalyst $(\mathrm{Fe})$ should contribute a lot on the formation of PCDD/Fs.

The results pave the way for further optimization on the operation of co-combustion of coal and SS and assist in controlling the PCDD/F emission from co-combustion process.

\section{ACKNOWLEDGMENTS}

This study was supported by the National Key Research and Development Program of PCDD/F China (2020YFC1910100).

\section{SUPPLEMENTARY MATERIAL}

Supplementary material for this article can be found in the online version at https://doi. org/10.4209/aaqr.210179

\section{REFERENCES}

Babushok, V.I., Tsang, W. (2003). Gas-phase mechanism for dioxin formation. Chemosphere 51, 1023-1029. https://doi.org/10.1016/S0045-6535(02)00716-6

Bhavsar, S.P., Reiner, E.J., Hayton, A., Fletcher, R., Macpherson, K. (2008). Converting Toxic Equivalents (TEQ) of dioxins and dioxin-like compounds in fish from one Toxic Equivalency Factor (TEF) scheme to another. Environ. Int. 34, 915-921. https://doi.org/10.1016/j.envint.20 08.02.001

Chanaka Udayanga, W.D., Veksha, A., Giannis, A., Lisak, G., Lim, T. (2019). Effects of sewage sludge organic and inorganic constituents on the properties of pyrolysis products. Energy Convers. Manage. 196, 1410-1419. https://doi.org/10.1016/j.enconman.2019.06.025 
Chen, T., Zhan, M., Lin, X., Li, X., Lu, S., Yan, J., Buekens, A., Cen, K. (2014). Inhibition of the de novo synthesis of PCDD/Fs on model fly ash by sludge drying gases. Chemosphere 114, 226232. https://doi.org/10.1016/j.chemosphere.2014.03.123

Cunliffe, A.M., Williams, P.T. (2009). De-novo formation of dioxins and furans and the memory effect in waste incineration flue gases. Waste Manage. 29, 739-748. https://doi.org/10.1016/j. wasman.2008.04.004

Evans, C.S., Dellinger, B. (2005). Mechanisms of dioxin formation from the high-temperature oxidation of 2-chlorophenol. Environ. Sci. Technol. 39, 122-127. https://doi.org/10.1021/es03 4387s

Intelligence Research Group (2019). Urban sludge treatment and disposal scale, sewage sludge production and sludge production forecast in 2018 in China. https://www.chyxx.com/industry/ 201912/822783.html

Kijo-Kleczkowska, A., Sroda, K., Otwinowski, H. (2013). Study into combustion of sewage sludge as energetic fuel. Arch. Min. Sci. 4, 1085-1110. https://doi.org/10.2478/amsc-2013-0075

Kijo-Kleczkowska, A., Sroda, K., Kosowska-Golachowska, M., Musiał, T., Wolski, K. (2016). Experimental research of sewage sludge with coal and biomass co-combustion, in pellet form. Waste Manage. 53, 165-181. https://doi.org/10.1016/j.wasman.2016.04.021

Lin, X., Chen, Z., Lu, S., Zhang, S., Zhang, M., Li, X., Yan, J. (2018). Emission characteristics of polychlorinated dibenzo-p-dioxins and dibenzofurans from the co-combustion of municipal solid waste in a lab-scale drop-tube furnace. Energy Fuel 32, 5396-5404. https://doi.org/10.10 21/acs.energyfuels.8b00408

Lomnicki, S., Dellinger, B. (2002). Formation of PCDD/F from the pyrolysis of 2-chlorophenol on the surface of dispersed copper oxide particles. Proc. Combust. Inst. 29, 2463-2468. https://doi.org/10.1016/S1540-7489(02)80300-5

Lomnicki, S., Dellinger, B. (2003). A detailed mechanism of the surface-mediated formation of PCDD/F from the oxidation of 2-chlorophenol on CuO/silica surface. J. Phys. Chem. A 107, 4387-4395. https://doi.org/10.1021/.jp026045z

López, N., Gómez-Segura, J., Marín, R.P., Pérez-Ramírez, J. (2008). Mechanism of $\mathrm{HCl}$ oxidation (Deacon process) over $\mathrm{RuO}_{2}$. J. Catal. 255, 29-39. https://doi.org/10.1016/j.jcat.2008.01.020

Luijk, R., Dorland, K., Smith, P., Govers, H. (1992). The halogenation of dibenzo-p-dioxin and dibenzofuran in a model fly ash system. Organohalogen Compd. 8, 273-276.

Ma, Y., Wang, P., Lin, X., Chen, T., Li, X. (2021). Formation and inhibition of Polychlorinated- $\rho$ dibenzodioxins and dibenzofurans from mechanical grate municipal solid waste incineration systems. J. Hazard. Mater. 403, 123812. https://doi.org/10.1016/j.jhazmat.2020.123812

Magdziarz, A., Werle, S. (2014). Analysis of the combustion and pyrolysis of dried sewage sludge by TGA and MS. Waste Manage. 34, 174-179. https://doi.org/10.1016/j.wasman.2013.10.033

Mckay, G. (2002). Dioxin characterisation, formation and minimisation during municipal solid waste (MSW) incineration: Review. Chem. Eng. J. 86, 343-368. https://doi.org/10.1016/S13858947(01)00228-5

Namkung, H., Lee, Y., Park, J., Song, G., Choi, J.W., Choi, Y., Park, S., Kim, J. (2018). Blending effect of sewage sludge and woody biomass into coal on combustion and ash agglomeration behavior. Fuel 225, 266-276. https://doi.org/10.1016/j.fuel.2018.03.109

Nganai, S., Dellinger, B., Lomnicki, S. (2014). PCDD/PCDF Ratio in the precursor formation model over CuO surface. Environ. Sci. Technol. 48, 13864-13870. https://doi.org/10.1021/es504253w

Ooi, T.C., Lu, L. (2011). Formation and mitigation of PCDD/Fs in iron ore sintering. Chemosphere 85, 291-299. https://doi.org/10.1016/j.chemosphere.2011.08.020

Pekárek, V., Grabic, R., Marklund, S., Punčocháŕ, M., Ullrich, J. (2001). Effects of oxygen on formation of PCB and PCDD/F on extracted fly ash in the presence of carbon and cupric salt. Chemosphere 43, 777-782. https://doi.org/10.1016/S0045-6535(00)00433-1

Raghunathan, K., Gullett, B.K. (1996). Role of sulfur in reducing PCDD and PCDF formation. Environ. Sci. Technol. 30, 1827-1834. https://doi.org/10.1021/es950362k

Ryu, J., Mulholland, J.A., Chu, B. (2003). Chlorination of dibenzofuran and dibenzo-p-dioxin vapor by copper (II) chloride. Chemosphere 51, 1031-1039. https://doi.org/10.1016/S0045-6535(02) 00844-5

Shanghai Municipal Bureau of Ecology and Environment (2021). Emission standard of air pollutants for coal \& sludge co-fired power plant._13. 
Shao, K., Yan, J., Li, X., Lu, S., Wei, Y., Fu, M. (2010). Inhibition of de novo synthesis of PCDD/Fs by $\mathrm{SO}_{2}$ in a model system. Chemosphere 78, 1230-1235. https://doi.org/10.1016/j.chemosphere. 2009.12.043

Stanmore, B.R. (2004). The formation of dioxins in combustion systems. Combust. Flame 136, 398-427. https://doi.org/10.1016/j.combustflame.2003.11.004

Stieglitz, L. (1998). Selected topics on the de novo synthesis of PCDD/PCDF on fly ash. Environ. Eng. Sci. 15, 5-18. https://doi.org/10.1089/ees.1998.15.5

Tan, P., Ma, L., Xia, J., Fang, Q., Zhang, C., Chen, G. (2017). Co-firing sludge in a pulverized coalfired utility boiler: Combustion characteristics and economic impacts. Energy 119, 392-399. https://doi.org/10.1016/j.energy.2016.12.084

United States Environmental Protection Agency (U.S. EPA) (1994). Method 1613, Revision B: Tetra-through octa-Chlorinated Dioxins and Furans by Isotope Dilution HRGC/HRMS., United States Environmental Protection Agency, Washington D.C.

Weber, P., Dinjus, E., Stieglitz, L. (2001). The role of copper(II) chloride in the formation of organic chlorine in fly ash. Chemosphere 42, 579-582. https://doi.org/10.1016/S0045-6535(00)00230-7

Werle, S., Wilk, R.K. (2010). A review of methods for the thermal utilization of sewage sludge: The Polish perspective. Renewable Energy 35, 1914-1919. https://doi.org/10.1016/j.renene.2 010.01.019

Wikström, E., Ryan, S., Touati, A., Telfer, M., Tabor, D., Gullett, B.K. (2003). Importance of chlorine speciation on de novo formation of polychlorinated dibenzo- $p$-dioxins and polychlorinated dibenzofurans. Environ. Sci. Technol. 37, 1108-1113. https://doi.org/10.1021/es026262d

Xia, Z., Zheng, L., Zhou, C., Wei, X., Dong, X. (2021). Combustion characteristics and kinetics during co-combustion of bituminous coal in Linhuan Mining Area, Anhui Province and municipal sludge. Chin. J. Process Eng. 21, 108-115 (in Chinese).

Yang, Z., Zhang, Y., Liu, L., Wang, X., Zhang, Z. (2016). Environmental investigation on cocombustion of sewage sludge and coal gangue: $\mathrm{SO}_{2}, \mathrm{NO}_{x}$ and trace elements emissions. Waste Manage. 50, 213-221. https://doi.org/10.1016/j.wasman.2015.11.011

Zhang, C., Zhu, T., Yin, L., Fang, Q., Zhan, Z., Xu, Q., Chen, G. (2015). Field test and numerical simulation for co-combustion of sludge in a MW coal fired boiler. J. Combust. Sci. Technol. 21, 114-123. http://doi.org/10.3969/j.issn.1002-3364.2015.06.001 (in Chinese).

Zhang, M., Yang, J., Buekens, A., Olie, K., Li, X. (2016). PCDD/F catalysis by metal chlorides and oxides. Chemosphere 159, 536-544. https://doi.org/10.1016/j.chemosphere.2016.06.049

Zhu, T., Yin, L., Zhang, C., Fang, Q., Xu, Q., Chen, G. (2015). Eddy-dissipation model based numerical simulation on co-combustion characteristics of a coal-fired boiler co-firing with different kinds of sludge. Thermal Power Generation 44, 1-9. http://doi.org/10.3969/j.issn.10 02-3364.2015.06.001 (in Chinese). 